\title{
FAKTOR-FAKTOR YANG MEMPENGARUHI KINERJA PERUSAHAN NON KEUANGAN
}

\author{
Dennies Christoper Jordan \\ Program Studi Magister Manajemen Universitas Tarumanagara \\ christoperden@gmail.com
}

\begin{abstract}
Penelitian ini bertujuan untuk menganalisa variabel yang mempengaruhi kinerja keuangan perusahaan yang termasuk dalam perusahaan publik non keuangan. Variabel yang digunakan adalah leverage, pertumbuhan, ukuran perusahaan, risiko keuangan, tangibilitas, likuiditas, non-debt tax shield, ukuran dewan direksi dan ukuran komite audit. Penelitian ini juga menguji konsistensi hasil penelitian sebelumnya. Sampel dari penelitian ini terdiri dari 716 data dari 179 perusahaan non keuangan yang terdaftar di Bursa Efek Indonesia dari tahun 2010 sampai dengan 2014 dan dipilih dengan metode purposive sampling, Data tersebut dianalisa dengan analisa regresi berganda untuk mengetahui pengaruh dari variabel independen terhadap kinerja keuangan perusahaan. Hasil penelitian menunjukkan bahwa leverage, ukuran perusahaan, tangibilitas, non-debt tax shield dan ukuran komite audit memiliki pengaruh terhadap kinerja keuangan perusahaan. Sementara, pertumbuhan, risiko keuangan, likuiditas dan ukuran dewan direksi tidak memiliki pengaruh terhadap kinerja keuangan perusahaan.
\end{abstract}

Abstract: This study aims to analyze variables that influence company's financial performance in non financial public companies. These variables are leverage, growth, firm size, financial risk, tangibility, liquidity, non debt tax shield, board of direction size and audit comitee size. This study was also Improve consistency of result from prior studies. The samples of this study consist of 716 data from 179 non financial companies that have been listing on Indonesia Stock Exchange from 2010 until 2014 and selected by purposive sampling method. Those data were analized using multiple regression analysis to investigate influence from independent variables to company's financial performance. The result from this study shows that leverage, firm size, tangibility, non debt tax shield and audit comitee size have influence to company's financial performance. However, growth, financial risk, liquidity and board of direction size do not have influence to company's financial performance.

Keywords: Financial Performance, Leverage, Growth, Firm Size, Financial Risk, Tangibility, Liquidity, Non Debt Tax Shield, Board of Direction Size, Audit Comitee Size.

Laporan keuangan menjadi pemegang peran penting dalam memberikan informasi kepada para investor agar bisa menilai kinerja perusahaan agar mereka tertarik untuk menanamkan modalnya. Laporan keuangan berkaitan erat dengan kinerja perusahaan, karena melalu laporan keuangan suatu perusahaan kita dapat melihat baik atau buruknya kinerja perusahaan selama periode berjalan. Kita dapat melihat apakah menguntungkan atau merugikan perusahaan dalam pasar modal dan kemampuan perusahaan untuk memaksimalkan kesejahterahan pemegang saham serta kemampuan perusahaan untuk mengelolah sumber daya yang dimiliki.

Kinerja perusahaan dapat digambarkan oleh profitabilitas atau kemampuan perusahaan tersebut menghasilkan laba. Profitabilitas sangat diperlukan untuk menilai kesuksesan perusahaan dalam hal kapabilitas dan motivasi dari manajemen. Pengukuran kinerja perusahaan dapat menjadi alat untuk menciptakan proyeksi laba perusahaan karena menggambarkan kolerasi antara laba dan jumlah modal yang ditanamkan. Selain itu, 
mengukur kinerja perusahaan dapat membantu pengendalian manajemen dan dapat membantu pihak internal untuk menyusun target, budget, koordinasi, evaluasi hasil eksekusi operasi serta sebagai dasar pengambilan keputusan.

\section{KERANGKA TEORITIS DAN PENGEMBANGAN HIPOTESIS Pecking Order Theory}

Pecking Order Theory yang dikembangkan oleh Myers dan Majluf (1984) adalah teori yang menyatakan bahwa perusahaan mengikuti suatu hirarki dalam pengambilan keputusan keuangan yang menyangkut struktur modalnya. Perusahaan lebih menyukai sumber pendanaan dari internal dan dalam hal mereka memerlukan pendanaan dari pihak eksternal, perusahaan akan menggunakan pendanaan yang paling aman terlebih dahulu, dimulai dari hutang, kemudian hutang yang bisa dikonversikan (convertible debt) dan pada akhirnya menerbitkan saham sebagai sumber pendanaan terakhir.

Perusahaan enggan dalam menerbitkan saham atau ekuitas baru dikarenakan adanya asymmetric information antara manajemen dan calon investor atau pemegang saham baru. Myers dan Majluf (1984) menyatakan bahwa akibat minimnya informasi yang dimiliki oleh calon investor dibandingkan manajemen perusahaan mengenai arus kas yang diharapkan dari asset perusahaan baik arus kas saat ini atau arus kas masa mendatang dan karena asumsi bahwa manajemen perusahaan tidak memihak mereka, menyebabkan ekuitas akan dinilai lebih rendah dari nilai intrinsiknya. Kesadaran bahwa investor memiliki sedikit informasi tentang perusahaan, maka investor akan berasumsi bahwa manajemen hanya akan menerbitkan saham jika harga saham tersebut sedang overpriced sehingga pasar akan menilai saham tersebut dengan diskon. Underpricing akan menyebabkan underinvestment, karena jika penerbitan saham pada nilai yang tidak menguntungkan maka hal ini akan dianggap sebagai pemindahan kekayaan dari pemegang saham lama ke pemegang saham baru. Bagi manajemen perusahaan terdapat aturan pengambilan keputusan pendanaan sebagai berikut, "Melakukan pinjaman atau berhutang ketika investor menilai perusahaan di bawah nilai intrinsiknya dan menerbitkan ekuitas jika terjadi sebaliknya yaitu investor menilai perusahaan di atas nilai intrinsiknya".

\section{Agency Theory}

Teori keagenan pertama kali dikemukakan oleh Jensen dan Meckling (1976). Teori ini membahas mengenai hubungan antara principal dengan agent. Yang dimaksud dengan principal adalah pemilik perusahaan atau pemegang saham, sedangkan agent adalah manajer perusahaan. Teori keagenan membuat sebuah hubungan kontraktual antara pemilik dan manajer dimana pemilik perusahaan mendelegasikan suatu tugas pengambilan keputusan kepada manajer sesuai dengan kontrak kerja.

Munculnya masalah-masalah yang disebabkan oleh konflik kepentingan dan asimetri informasi dapat membuat perusahaan menanggung biaya keagenan (agency cost). Menurut Jensen dan Meckling (1976) terdapat tiga macam biaya keagenan (agency cost), diantaranya Monitoring Cost, yaitu biaya yang dikeluarkan dengan tujuan untuk membatasi penyimpangan yang dilakukan oleh pihak manajer dengan memonitor aktivitas yang dilakukan oleh manajer. Bonding Cost, dalam beberapa situasi tertentu, pihak agent diberikan kesempatan untuk membelanjakan sumber daya perubahan yang diharapkan dapat menjamin bahwa manajer tidak akan merugikan pemilik. Residual Loss, merupakan nilai uang yang ekuivalen dengan kesejahteraan yang dialami oleh pemilik, biaya ini dianggap sebagai biaya yang timbul dari hubungan keagenan dan dinamakan biaya kerugian residual.

\section{Kinerja Perusahaan}

Kinerja keuangan merupakan ukuran keberhasilan atas pelaksanaan fungsi-fungsi keuangan dan hal ini sangat penting, baik bagi investor maupun bagi perusahaan yang 
bersangkutan. Pentingnya penilaian prestasi kinerja perusahaan dengan melakukan analisis terhadap laporan keuangan telah memicu pemikiran para pemimpin perusahaan bahwa mengelola suatu perusahaan di era modern dengan perkembangan teknologi yang pesat menjadi hal yang sangat kompleks. (Noviawan dan Septiani, 2013)

Izati dan Margaretha (2014) menyatakan bahwa tujuan utama dari perusahaan adalah untuk memaksimalkan nilai, keuntungan, dan kesejahteraan pemegang saham. Oleh karena itu profitabilitas perusahaan telah menjadi kriteria utama dalam menentukan kinerja keuangan.

$$
\mathrm{ROA}=\frac{\text { Earning Before Interest and Tax }}{\text { Total Assets }}
$$

\section{Leverage dan Kinerja Perusahaan}

Menurut Gitman dan Zutter (2012) leverage mengacu pada efek yang dimiliki biaya tetap pada pengembalian yang diperoleh pemegang saham. Leverage yang lebih tinggi umumnya menghasilkan keuntungan yang lebih tinggi namun lebih stabil. Finance leverage menyebabkan membesarnya risiko dan pengembalian melalui penggunaan biaya tetap, seperti utang dan saham preferen.

LEV $=\frac{\text { Total Liabilities }}{\text { Total Assets }}$

$\mathrm{Ha}_{1}$ : Leverage berpengaruh terhadap Kinerja Perusahaan

\section{Pertumbuhan Perusahaan dan Kinerja Perusahaan}

Bhutta dan Hasan (2013) meyatakan pertumbuhan yang lebih baik dapat meningkatkan profitabilitas. Jika ada peningkatan total asset itu berarti memiliki pertumbuhan yang tinggi akan lebih menguntungkan. Pertumbuhan aktiva pada dasarnya menggambarkan bagaimana perusahaan menginvestasikan dana yang dimiliki untuk kegiatan operasi dan investasi.

$$
\text { GROWTH }=\frac{\text { Total Assets }_{t^{-}} \text {Total Assets }_{t-1}}{\text { Total Assets }_{t}}
$$

$\mathrm{Ha}_{2}:$ Pertumbuhan Perusahaan berpengaruh terhadap Kinerja Perusahaan

\section{Ukuran Perusahaan dan Kinerja Perusahaan}

Menurut Rajan dan Zingales (1995) dalam Izati dan Margaretha (2014) ukuran diharapkan menjadi salah satu faktor dalam kinerja perusahaan. Ukuran dapat memiliki efek positif pada kinerja perusahaan, karena perusahaan-perusahaan besar dapat memanfaatkan ukuran perusahaan untuk mendapatkan kesepakatan yang lebih baik di bidang keuangan.

Ha3: Ukuran Perusahaan berpengaruh terhadap Kinerja Perusahaan

\section{Risiko Keuangan dan Kinerja Perusahaan}

Pada umumnya investor akan memilih investasi dengan tingkat keuntungan yang lebih besar dengan tingkat risiko yang ditanggung sama, atau investasi dengan tingkat keuntungan sama tetapi risiko yang ditanggung lebih kecil. Di dalam analisa finansial leverage dikemukakan bahwa apabila beban-beban finansial meningkat maka EBIT pun harus diperbesar untuk dapat menutup kenaikan biaya tersebut. Jadi dapatlah dikatakan bahwa dengan meningkatnya leverage akan memperbesar risiko yang ditanggung oleh perusahaan (Izati dan Margaretha 2014).

$$
\text { RISK }=\frac{\text { Earning Before Interest and Tax }}{\text { Earning After Interest and Tax }}
$$


Ha4: Risiko Keuangan berpengaruh terhadap Kinerja Perusahaan

\section{Tangibilitas dan Kinerja Perusahaan}

Menurut Memon et al. (2010) Tangibilitas dapat diukur dengan total fixed asset dibagi dengan total asset dan tangible asset yang digunakan sebagai jaminan dan perusahaan yang memiliki lebih banyak tangible asset akan memiliki biaya pinjaman lebih rendah.

$$
\mathrm{TANG}=\frac{\text { Fixed } A \text { ssets }}{\text { Total } \text { Assets }}
$$

Has: Tangibilitas berpengaruh terhadap Kinerja Perusahaan

\section{Likuiditas dan Kinerja Perusahaan}

Kemampuan relatif perusahaan untuk mengkonversi aset menjadi uang tunai yang juga dapat berdampak pada kinerja sebagai sumber daya yang cepat dapat digunakan untuk merespon peluang keuntungan. Semakin tinggi current ratio suatu perusahaan berarti semakin kecil resiko kegagalan perusahaan dalam memenuhi kewajiban jangka pendeknya. (Izati dan Margaretha 2014).

\begin{tabular}{|c|}
$\mathrm{CR}=\frac{\text { Current Assets }}{\text { Current Liabilities }}$ \\
\hline
\end{tabular}

Ha7: Non Debt Tax Shield berpengaruh terhadap Kinerja Perusahaan

\section{Ukuran Dewan Direksi dan Kinerja Perusahaan}

Menurut Kajola dan Sunday (2008), membatasi ukuran dewan direksi ke tingkat tertentu umumnya diyakini meningkatkan kinerja suatu perusahaan karena ukuran direksi yang lebih besar bermanfaat untuk peningkatan pengawasan yang sebanding dengan menurunnya komunikasi dan pengambilan keputusan kelompok yang lebih besar. Studi empiris pada ukuran dewan direksi memberikan kesimpulan pengaruh negatif yang cukup jelas antara ukuran dewan dan nilai perusahaan.

BOADSIZE $=$ jumlah seluruh dewan direksi

Has: Ukuran Dewan Direksi berpengaruh terhadap Kinerja Perusahaan

\section{Ukuran Komite Audit dan Kinerja Perusahaan}

Komite audit mengacu pada yang secara umum bertanggung jawab untuk mengawasi laporan keuangan dan berkomunikasi dengan perusahaan. Komite memberikan komunikasi bernilai antara auditor internal dan eksternal dan pimpinan membantu untuk memastikan itu mencakup semua isu yang relevan dengan audit. Peningkatan jumlah anggota komite audit menunjukkan lebih banyak ahli yang tersedia di tangan untuk menghadap pengendalian internal dan pelaporan keuangan (Kajola dan Sunday 2008).

\section{AUDITSIZE=jumlah seluruh komite audit}

Ha9: Ukuran Komite Audit berpengaruh terhadap Kinerja Perusahaan

\section{PEMILIHAN SAMPEL DAN PENGUMPULAN DATA}

Populasi yang digunakan dalam penelitian ini adalah perusahaan non keuangan yang terdaftar di Bursa Efek Indonesia. Obyek pengamatan menggunakan tahun penelitian 2011-2014. Sampel diambil dengan menggunakan metode purposive sampling, dimana setiap sampel yang digunakan harus memenuhi kriteria tertentu. Kriteria yang harus dipenuhi, antara lain: 
Tabel 1 Kriteria Pemilihan Sampel

\begin{tabular}{lrr}
\hline Keterangan & Jumlah perusahaan & Total \\
\hline $\begin{array}{l}\text { Perusahaan non keuangan yang terdaftar di } \\
\text { Bursa Efek Indonesia selama periode 2010-2014 }\end{array}$ & 335 & 1340 \\
\hline $\begin{array}{l}\text { Perusahaan non keuangan yang tidak } \\
\text { menggunakan mata uang Rupiah }\end{array}$ & $(67)$ & $(268)$ \\
\hline $\begin{array}{l}\text { Perusahaan non keuangan yang tidak } \\
\text { melaporkan laporan keuangan per 31 desember }\end{array}$ & $(3)$ & $(12)$ \\
\hline $\begin{array}{l}\text { Perusahaan non keuangan yang tidak } \\
\text { melaporkan laba setelah pajak positif selama } \\
\text { periode 2011-2014 }\end{array}$ & & $(344)$ \\
\hline Perusahaan yang dijadikan sampel & $\mathbf{1 7 9}$ & $\mathbf{7 1 6}$ \\
\hline Jumlah data & & $\mathbf{7 1 6}$ \\
\hline
\end{tabular}

\section{HASIL PENELITIAN}

Statistik deskriptif memberikan gambaran data yang dilihat dari nilai rata-rata, minimum, maksimum dan standar deviasi. Hasil pengolahan statistik deskriptif dan pengujian Hipotesis adalah sebagai berikut:

Tabel 2 Hasil Uji Statistik Deskriptif

\begin{tabular}{lrrrrr}
\hline & N & Minimum & Maximum & Mean & Std. Deviation \\
\hline ROA & 716 & -0.00689 & 0.63928 & 0.12301 & 0.09866 \\
LEV & 716 & 0.00032 & 2.11556 & 0.44993 & 0.20706 \\
GROWTH & 716 & -0.55254 & 426.57725 & 0.81823 & 15.93981 \\
FIRMSIZE & 716 & 21.37947 & 32.93781 & 28.02187 & 1.81683 \\
RISK & 716 & -2.41914 & 353.27032 & 2.99656 & 14.29420 \\
TANG & 716 & 0.00117 & 0.85056 & 0.27553 & 0.20873 \\
CR & 716 & 0.16561 & 247.12707 & 2.75234 & 10.95574 \\
NDTS & 716 & 0.00308 & 0.69442 & 0.15023 & 0.10522 \\
BOADSIZE & 716 & 2 & 16 & 5.08 & 2.159 \\
AUDITSIZE & 716 & 2 & 7 & 3.07 & 0.464
\end{tabular}

Sumber: Pengolahan data SPSS 19

\begin{tabular}{lrrrl}
\hline Variabel & B & Error & Sig. & Kesimpulan \\
\hline (Constant) & -0.016 & -0.944 & 0.346 & \\
LEV & -0.017 & -3.741 & 0.000 & Terdapat Pengaruh \\
GROWTH & $-4.963 \mathrm{E}-$ & -0.074 & 0.941 & Tidak Terdapat Pengaruh \\
& 6 & & & \\
FIRMSIZE & 0.001 & 2.052 & 0.041 & Terdapat Pengaruh \\
RISK & $1.1558 \mathrm{E}-$ & 0.180 & 0.857 & Tidak Terdapat Pengaruh \\
& 5 & & & \\
TANG & -0.059 & -13.208 & 0.000 & Terdapat Pengaruh \\
CR & $1.584 \mathrm{E}-5$ & 0.157 & 0.875 & Tidak Terdapat Pengaruh \\
NDTS & 0.908 & 97.502 & 0.000 & Terdapat Pengaruh \\
BOADSIZE & 0.000 & 0.382 & 0.702 & Tidak Terdapat Pengaruh \\
AUDITSIZE & -0.004 & -2.047 & 0.041 & Terdapat Pengaruh \\
\hline
\end{tabular}


Leverage (LEV) memiliki nilai signifikansi lebih kecil dari alpha $(\alpha=0.05)$ yaitu sebesar 0.000. Hal ini menunjukkan bahwa leverage memiliki pengaruh terhadap kinerja perusahaan. Myers (1977) dalam Izati dan Margaretha (2014) menyatakan leverage yang lebih tinggi berarti biaya keagenan tinggi karena perbedaan kepentingan antara pemegang saham dan debtholders, masalah ini menunjukkan pengaruh negatif dengan kinerja.

Pertumbuhan Perusahaan (GROWTH) memiliki nilai signifikansi lebih besar dari alpha $(\alpha=0.05)$ atau sebesar 0.941. Ini menunjukkan bahwa Pertumbuhan Perusahaan tidak berpengaruh terhadap Kinerja Perusahaan.

Ukuran Perusahaan (FIRMSIZE) memiliki nilai signifikansi lebih kecil dari alpha $(\alpha=0.05)$ yaitu sebesar 0.041. Ini menunjukkan bahwa ukuran perusahaan berpengaruh terhadap Kinerja Perusahaan. Perusahaan yang lebih besar memiliki lebih sedikit risiko terlibat dalam operasi dan memiliki biaya kebangkrutan terendah, sehingga, diasumsikan bahwa ukuran perusahaan memiliki dampak positif pada kinerja perusahaan (Memon et al. 2010).

Risiko Keuangan (RISK) memiliki nilai signifikansi lebih dari alpha $(\alpha=0.05)$ atau sebesar 0.857. Hal ini menunjukkan bahwa Risiko Keuangan tidak memiliki pengaruh terhadap Kinerja Perusahaan.

Tangibilitas (TANG) memiliki nilai signifikansi lebih kecil dari alpha $(\alpha=0.05)$ atau sebesar 0.000. Ini menunjukkan $\mathrm{Ha}_{5}$ diterima dan dapat disimpulkan bahwa Tangibilitas memiliki pengaruh terhadap Kinerja Perusahaan. Riyanto (2013) dalam Izati dan Margaretha (2014) menyatakan Investasi dalam aktiva tetap menyangkut harapan terhadap hasil penjualan diwaktu yang akan datang. Apabila investasi dalam aktiva tetap terlalu besar melebihi daripada yang diperlukan akan memberikan beban tetap yang besar bagi perusahaan.

Likuditas (CR) memiliki nilai signifikansi lebih besar dari alpha $(\alpha=0.05)$ atau sebesar 0.875 . Hal ini menunjukkan bahwa likuiditas tidak memiliki pengaruh terhadap Kinerja Perusahaan.

Non Debt Tax Shield (NDTS) memiliki nilai signifikansi lebih kecil dari alpha $(\alpha=0.05)$ atau sebesar 0.000. Ini menunjukkan bahwa Non Debt Tax Shield berpengaruh terhadap Kinerja Perusahaan. Myers (1984) dalam Izati dan Margaretha (2014) menyatakan bahwa perusahaan dengan Non Debt Tax Shields tinggi akan menurunkan tingkat utang perusahaan jika keuntungan (laba) perusahaan meningkat.

Ukuran Dewan Direksi (BOADSIZE) memiliki nilai signifikansi lebih besar dari alpha $(\alpha=0.05)$ yaitu sebesar 0.702. Ini menunjukkan bahwa Ukuran Dewan Direksi tidak berpengaruh terhadap Kinerja Perusahaan.

Ukuran Komite Audit (AUDITSIZE) memiliki nilai signifikansi lebih kecil dari alpha $(\alpha=0.05)$ yaitu sebesar 0.041 . Hal ini menunjukkan bahwa Ukuran Komite Audit memiliki pengaruh terhadap Kinerja Perusahaan. Menurut Noviawan dan Septiani (2013) hal ini disebabkan karena keberadaan komite audit dalam perusahaan yang telah diatur oleh peraturan Bapepam Kep 29/PM/2004 tentang peraturan nomor IX.1.5 membuat perusahaan hanya sebatas menjalankan formalitas dalam menaati peraturan tentang jumlah komite audit ini menyebabkan efektivitas komite audit dalam menjalankan fungsi pengawasan menjadi kurang baik.

\section{PENUTUP}

Berdasarkan hasil pengujian hipotesis penelitian ini, maka dapat disimpulkan bahwa Leverage, Ukuran Perusahaan, Tangibilitas, Non Debt Tax Shield dan Ukuran Komite Audit memiliki pengaruh terhadap Kinerja Perusahaan. Sedangkan Pertumbuhan Perusahaan, Risiko Keuangan, Likuiditas dan Ukuran Dewan Direksi tidak memiliki pengaruh terhadap Kinerja Perusahaan. 


\section{REFERENSI}

Bhutta, Nousheen T. dan Arshad Hasan. 2013.Impact of Firm Specific Factors on Profitability of Firms in Food Sector. Open Journal of Accounting.

Gitman, Lawrence J. dan Chad J. Zutter 2012. Principles of Managerial Finance. 13th Edition.United States: Prentice Hall

Izati, Chaerunisa dan Farah Margaretha. 2014. Faktor-Faktor Yang Mempengaruhi Kinerja Keuangan Pada Perusahaan Basic Industry and Chemicals Di Indonesia. e-Journal Manajemen Fakultas Ekonomi Universitas Trisakti.

Jensen, Michael C. dan William H. Meckling. 1976. Theory of the firm: managerial behavior, agency costs and ownership structure. Financial Economics.

Kajola dan Sunday O. 2008. Corporate Governance and Firm Performance: The Case of Nigerian Listed Firms. European Journal of Economics, Finance and Administrative Sciences.

Memon, Fozia., Niaz A. Bhutto, dan Ghulam Abbas. 2010. Capital Structure and firm's performance: A case of Textile sector Pakistan. Asian Journal of Business and Management Science.

Myers, Steward C., dan Majluf Nicholas S. 1984. Corporate Financing and Investment Decisions When Firms Have Information That Investors Do Not Have. Journal of Financial Economics.

Noviawan, Ridho A. dan Aditya Septiani. 2013. Pengaruh Mekanisme Corporate

Governance Dan Struktur Kepemilikan Terhadap Kinerja Keuangan. Diponegoro Journal of Accounting. 
